\title{
Differences between blood and plasma concentrations of acetate, $\beta$-hydroxybutyrate, glucose, ammonia and urea: implications for measurement of portal net fluxes in ewes
}

\author{
Pierre Nozière $^{a *}$, Didier Rémond $^{\mathrm{b}}$, Anne Ferlay $^{\mathrm{a}}$, Michel Doreau ${ }^{\mathrm{a}}$ \\ ${ }^{\text {a }}$ Laboratoire sous-nutrition des ruminants, Inra-Theix, 63122 Saint-Genès-Champanelle, France \\ ${ }^{\mathrm{b}}$ Station de recherches sur la nutrition des herbivores, Inra-Theix, \\ 63122 Saint-Genès-Champanelle, France
}

(Received 18 May 1998; accepted 5 October 1998)

\begin{abstract}
The aim of this study was to determine the differences in concentrations of various metabolites between blood and plasma, and their implications for the measurement of portal net fluxes in ewes. A wide range of concentrations of metabolites in arterial and portal blood was induced by submitting three ewes to three different levels of intake. Plasma measurements underestimated the portal drained viscera net flux for acetate, glucose, ammonia and urea but not for $\beta$-hydroxybutyrate. The underestimation of net release was low and largely constant for acetate (7\%). The net flux of glucose tended to be overestimated by plasma measurements when it was low, but was underestimated by $25 \%$ when high net uptake occurred. The underestimation of net fluxes of ammonia and urea increased with their magnitude, up to $17 \%$ for ammonia release and $41 \%$ for urea uptake. (c) Inra/ Elsevier, Paris.
\end{abstract}

net flux of metabolites / portal drained viscera / ruminant / blood / plasma

Résumé - Différences de concentrations en acétate, $\beta$-hydroxybutyrate, glucose, ammoniac et urée entre le sang et le plasma : impact sur la mesure des flux nets au niveau de la veine porte chez la brebis. L'objectif de cette étude était de déterminer les différences de concentration en métabolites entre le sang et le plasma, et leur impact sur la mesure des flux nets au niveau de la veine porte, chez la brebis. Une large fourchette de variation des concentrations sanguines en métabolites dans le sang artériel et porte a été induite en soumettant trois brebis à trois niveaux d'alimentation différents. Les mesures plasmatiques sous-estiment les flux nets au niveau de la veine porte pour l'acétate, le glucose, l'ammoniac et l'urée, mais pas pour le $\beta$-hydroxybutyrate. La sous-estimation de l'absorp-

\footnotetext{
* Correspondence and reprints

E-mail: noziere@clermont.inra.fr
} 
tion nette est faible et constante pour l'acétate $(7 \%)$. Le flux net de glucose tend à être surestimé par les mesures plasmatiques lorsqu'il est faible, mais est sous-estimé de $25 \%$ lorsque l'utilisation nette est importante. L'amplitude de la sous-estimation du flux net d'ammoniac et d'urée augmente avec l'intensité du flux, jusqu'à $17 \%$ pour l'absorption d'ammoniac et $41 \%$ pour l'utilisation d'urée. (C) Inra/Elsevier, Paris.

flux net de métabolites / viscères / veine porte / ruminant / sang / plasma

\section{INTRODUCTION}

Many studies in ruminant nutrition focus on quantitative measurements of net metabolite flux through portal-drained viscera (PDV). Net flux is calculated as the product of portal blood (or plasma) flow and the concentration difference between portal and arterial blood (or plasma). Due to problems inherent in sample preparation and/or storage of blood, most data have been obtained using plasma. However, blood cells can be involved to a non-negligible degree in the transport of several metabolites, as demonstrated in sheep for acetate [1] or amino acids [7]. Therefore, knowing whether to analyse blood or plasma has become increasingly important. In ruminants, some studies have already focused on differences between blood and plasma concentrations of various metabolites and their effect on measurements of net PDV flux [8, 9, 18]. Plasma measurements appear to underestimate net release of ammonia, $\alpha$-amino $\mathrm{N}$, acetate, propionate, i-butyrate and 2-methylbutyrate, and net uptake of glucose and urea. The extent of the underestimation would be expected to vary according to the magnitude of the metabolite flux through PDV, but this is unproven. The aim of the present study was to induce a wide range of concentrations of metabolites in arterial and portal blood by submitting ewes to three different levels of intake, and to determine the differences in concentration and PDV net flux between blood and plasma for acetate, $\beta$-hydroxybutyrate, glucose, ammonia and urea.

\section{MATERIALS AND METHODS}

\subsection{Animals, housing and feeding}

Three adult, non-pregnant, non-lactating Limousin $\times$ Romanov ewes $(55.5 \pm 6.9 \mathrm{~kg}$ body weight) were used. They were surgically fitted with chronic catheters in the portal vein, a mesenteric artery and a mesenteric vein, as described by Ortigues et al. [15]. The animals were allowed $10 \mathrm{~d}$ to recover from surgery and were then housed in an air-conditioned room in individual boxes $\left(1.5 \mathrm{~m}^{2}\right)$.

Animals were fed, in a $3 \times 3$ Latin square experimental design, 355, 662 and $1004 \mathrm{~g} \cdot \mathrm{d}^{-1}$, on dry matter (DM) intake basis, of a diet consisting of regrowth of natural grassland hay, with net energy (NE) and protein contents estimated at $5.614 \mathrm{MJ}$ and $83 \mathrm{~g}$ PDI (protein digestible in the intestine) $\mathrm{kg}^{-1} \mathrm{DM}$ [11]. These diets covered, respectively, 47,86 and $126 \%$ of the NE requirements and 62,113 and $165 \%$ of the protein requirements, taken according to the French systems [11] as $0.213 \mathrm{MJ} \mathrm{NE}$ and $2.4 \mathrm{~g}$ PDI per $\mathrm{kg}$ of metabolic body weight. They also received $10 \mathrm{~g} \cdot \mathrm{d}^{-1}$ of a mineral supplement $(\mathrm{Ca} / \mathrm{P} / \mathrm{Mg}=$ 15:10:2\%) containing vitamins and microelements and had free access to water and block salt. Hay was offered every $3 \mathrm{~h}$ (eight equal meals per day with an automatic feeder). After each change of level of intake, an adaptation period of $10 \mathrm{~d}$ was allowed before blood sampling.

\subsection{Blood sampling and measurements}

Animals were sampled for $2 \mathrm{~d}$ per period. They were allowed $1 \mathrm{~d}$ for recovery between the two sampling days. On each sampling day, $p$-aminohippuric acid (PAH) dissolved (10\% w/v) in a physiological sterile saline solution ( $\mathrm{pH} 7.4)$ 
was infused continuously via the mesenteric vein (7.2 $\left.\mathrm{mL} \cdot \mathrm{h}^{-1}\right)$ after a prime injection ( $2.25 \mathrm{~mL})$. Infusion started $45 \mathrm{~min}$ before sampling. A total of 12 blood samples of $7 \mathrm{~mL}$ were taken each day from the mesenteric artery and portal vein over two feeding cycles (i.e. $6 \mathrm{~h}$ ) using syringes containing EDTA-K as anticoagulant. Sampling started 15 min after a meal and was repeated at intervals of $30 \mathrm{~min}$. Immediately after sampling, blood was gently homogenized and packed cell volume (PCV) was determined in triplicate by centrifuging whole blood in capillary tubes.

A representative sample of whole blood was centrifuged $\left(3000 \mathrm{~g}, 10 \mathrm{~min}, 4^{\circ} \mathrm{C}\right.$ ) for plasma preparation. Accidentally hemolysed samples were discarded. One millilitre of blood and plasma was diluted $(1: 1)$ with $\mathrm{H}_{2} \mathrm{O}$ and stored at $-20{ }^{\circ} \mathrm{C}$ before colorimetric determination of $\mathrm{PAH}$, ammonia and urea using a continuous autoanalyser (Alliance, Méry-sur-Oise, France). PAH was determined in triplicate by the automated $N$ - $\alpha$-naphthyl ethylene diamine dichlorohydrate method [6], as described by Isserty et al. [12]. Ammonia and urea were determined in triplicate by the automated phenol-hypochlorite [21] and diacetylmonoxime [14] methods, as described by Rémond et al. [17]. One millilitre of whole blood was deproteinized by adding $2 \mathrm{~mL}$ of $\mathrm{HClO}_{4} 6 \%(\mathrm{w} / \mathrm{v})$. Supernatant and plasma were stored at $-20^{\circ} \mathrm{C}$ before enzymatic determination in duplicate of acetate [5] (Boehringer Mannheim, Meylan, France), $\beta$-hydroxybutyrate [4] and glucose [5] (Merckotest, Merck, Nogent-sur-Marne, France) using a multianalyser (Elan, MerckClevenot, Nogent-sur-Marne, France).

\subsection{Calculations and statistical analyses}

Concentration of PAH and metabolites within the cell fraction $(\mathrm{C}, \mathrm{mM})$ was calculated with the following equation:

$$
\mathrm{C}=[\mathrm{B}-\mathrm{P}(1-\mathrm{PCV})] / \mathrm{PCV}
$$

where $\mathrm{B}$ and $\mathrm{P}$ are the concentrations of metabolite $(\mathrm{mM})$ in blood and plasma, respectively.

Blood (or plasma) flow (F, L. $h^{-1}$ ) and net flux of metabolite (NF, $\mathrm{mmol} \cdot \mathrm{h}^{-1}$ ) through PDV were calculated as described by Katz and Bergman [13]:

$$
\begin{gathered}
\mathrm{F}=\mathrm{I} /\left(\mathrm{PAH}_{\mathrm{pv}}-\mathrm{PAH}_{\mathrm{ma}}\right) \\
\mathrm{NF}=\mathrm{F}\left(\mathrm{N}_{\mathrm{pv}}-\mathrm{N}_{\mathrm{ma}}\right)
\end{gathered}
$$

where $\mathrm{I}$ is $\mathrm{PAH}$ infusion rate $\left(\mathrm{g} \cdot \mathrm{h}^{-1}\right), \mathrm{PAH}_{\mathrm{pv}}$,
$\mathrm{PAH}_{\mathrm{ma}}, \mathrm{N}_{\mathrm{pv}}$ and $\mathrm{N}_{\mathrm{ma}}$ are concentrations of PAH $\left(\mathrm{g} \cdot \mathrm{L}^{-1}\right)$ and metabolite $(\mathrm{mM})$ in portal vein and mesenteric arterial blood (or plasma), respectively. Positive net flux represented net release in the portal vein, whereas negative net flux represented net uptake by PDV.

For PAH and each metabolite, blood and plasma or cell concentrations were compared by paired $t$-tests in both artery and portal vein. When differences were significant $(P<0.05)$, a linear relationship was established between blood and plasma concentrations for each sampling site, and the slopes of the relationships were compared between artery and portal vein by an F-test.

Flows and metabolite fluxes were compared between blood and plasma by paired $t$-tests. When differences were significant $(P<0.05)$, a linear relationship was established between blood and plasma measurements and the slope of the relationship was compared with 1 using an F-test.

All analyses were performed using the GLM procedure of SAS [20].

\section{RESULTS AND DISCUSSION}

\subsection{Concentration of metabolites in blood, plasma and cells}

On average, $\beta$-hydroxybutyrate, glucose and urea concentrations were higher $(P<0.001)$ in plasma than in whole blood in the artery as in the portal vein (table I). Similarly, acetate was more concentrated in plasma than in whole blood in the portal vein $(P<0.001)$, but an adverse trend was observed in the artery $(P<0.001)$. Ammonia was less concentrated in plasma than in whole blood in the artery $(P<0.001)$, whereas no significant differences were observed between plasma and blood in the portal vein. These results indicate that the distribution of the metabolites between cells and plasma is not homogeneous, concentrations being higher in the cell fraction than in plasma for acetate and ammonia in the artery $(P<0.001)$ and lower for the other metabolites $(P<0.001)$ in both artery and portal veins. The contribution of the cell fraction to whole blood concentration (calculated for each sample with its own PCV value, averaging $0.252 \pm 0.002$ ) was greater 


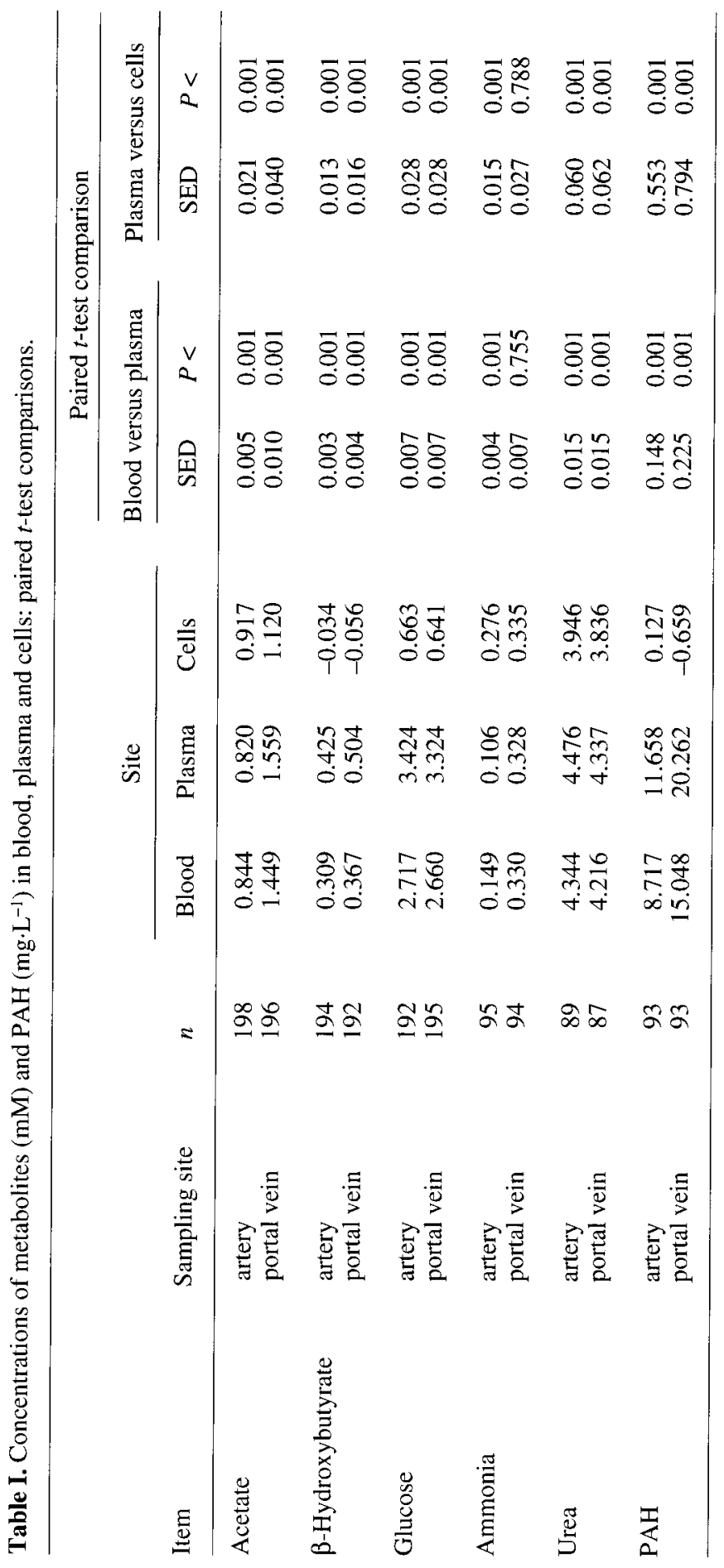


for ammonia, urea and acetate (on average 32,23 and $22 \%$, respectively) than for glucose and $\beta$-hydroxybutyrate (on average 6 and $0 \%$, respectively). In cattle, Reynolds and Huntington [18] observed a lower contribution of blood cells to whole blood concentrations of acetate $(10 \%)$ than that reported here $(22 \%)$. To our knowledge, no data were available concerning differences in $\beta$-hydroxybutyrate concentration between blood and plasma. Our results indicate that $\beta$-hydroxybutyrate is not linked to the cell fraction. Reynolds and Huntington [18] obtained similar results for butyrate, 2-methylbutyrate, valerate and i-valerate, calculated concentrations in the cell fraction being slightly negative. These results suggest that blood cell membrane permeability to volatile fatty acids (VFA) with a chain length of 4 and $5 \mathrm{C}$ is very low. Likewise, Aubert and Motais [3] observed that an organic acid with a chain length of more than $4 \mathrm{C}$ requires at least three oxygen atoms to react with complementary loci on the receptor of bovine erythrocytes to form ionic and hydrogen bonds. These authors also found that the penetration rate in bovine erythrocytes is 300 times lower for PAH than for acetate. This is in agreement with our results, where PAH concentration in blood cell was not different from zero (table I), indicating a low permeability of blood cell membranes for this organic acid. Huntington [9] reported a contribution of blood cells of $0 \%$ for glucose whole blood concentration. Our data indicate that contribution of blood cells to whole blood concentration of glucose is low but not null. Since glucose is taken up by erythrocytes by facilitated diffusion, the presence of glucose in blood cell fraction is not surprising, although sheep erythrocytes have a significant glycolytic activity [2]. From the data of Huntington [9] it can be calculated that the concentration in cells is higher for ammonia and lower for urea than in plasma, and that the contribution of blood cells to whole blood concentration is about $37 \%$ for ammonia and $22 \%$ for urea. These values are close to those found in the present study (32 and $23 \%$, respec- tively). Erythrocyte membranes are highly permeable to uncharged $\mathrm{NH}_{3}$ [3]; the high concentration in blood cells observed could be due to the accumulation of charged $\mathrm{NH}_{3}$ within the erythrocytes, $\mathrm{H}^{+}$coming fom carbonic acid dissociation within the cells. Urea concentration in blood cells is lower but close to plasma concentration. Urea transporters have been demonstrated in erythrocytes, and rapid exchanges between erythrocytes and plasma can occur [19].

The nutritional plan used in the present study induced a wide range of arterial and portal blood concentrations of metabolites: from 0.4 to $2.5 \mathrm{mM}$ for acetate, 0.2 to $0.5 \mathrm{mM}$ for $\beta$-hydroxybutyrate, 2.2 to $3.1 \mathrm{mM}$ for glucose, 0.1 to $0.5 \mathrm{mM}$ for ammonia and 2.9 to $6.8 \mathrm{mM}$ for urea. Within these ranges of metabolite concentrations, blood values were closely correlated $(P<0.001)$ to their paired plasma values (table II). The relationships were independent of the sampling site (artery or portal vein) for $\beta$-hydroxybutyrate, glucose and urea. In contrast, for acetate and ammonia, the slope of the relationship between blood and plasma concentrations was higher $(P<0.01)$ for portal than for arterial samples. The low correlation coefficient observed for ammonia at each sampling site can be related to the fact that ammonia concentration did not greatly vary in arterial (0.10-0.25 $\mathrm{mM})$ and portal (0.25-0.50 mM) blood. Moreover, compared with the other metabolites studied, large differences in ammonia and acetate concentrations were observed between arterial and portal blood (on average 0.844 versus $1.449 \mathrm{mM}$ for acetate and 0.149 versus $0.330 \mathrm{mM}$ for ammonia, respectively), and the contribution of the cell fraction to whole blood concentration was higher in the artery than in the portal vein: 27 versus $19 \%$ for acetate and 47 versus $26 \%$ for ammonia, respectively. These observations suggest that for these two metabolites, for which PDV net release is high, portal concentrations rose more rapidly in plasma than in blood cells. 
Table II. Linear relationships between blood (X) and plasma (Y) concentrations of metabolites $(\mathrm{mM})$ and PAH $\left(\mathrm{mg} \cdot \mathrm{L}^{-1}\right)$.

\begin{tabular}{|c|c|c|c|c|c|}
\hline \multirow[b]{2}{*}{ Item } & \multirow[b]{2}{*}{$n$} & \multicolumn{2}{|c|}{$\mathrm{Y}=\mathrm{a} X+\mathrm{b}$} & \multirow{2}{*}{$\begin{array}{l}\text { Interaction with } \\
\text { sampling site } P<\end{array}$} & \multirow[b]{2}{*}{$r$} \\
\hline & & Slope (a) & Intercept (b) & & \\
\hline Acetate & 394 & $1.208 \pm 0.008$ & $-0.196 \pm 0.074$ & 0.004 & 0.99 \\
\hline Artery & 198 & $1.149 \pm 0.016$ & $-0.150 \pm 0.059$ & - & 0.98 \\
\hline Portal vein & 196 & $1.217 \pm 0.013$ & $-0.205 \pm 0.085$ & - & 0.99 \\
\hline$\beta$-Hydroxybutyrate & 386 & $1.200 \pm 0.035$ & $0.059 \pm 0.046$ & 0.448 & 0.87 \\
\hline Glucose & 387 & $1.255 \pm 0.026$ & $-0.001 \pm 0.091$ & 0.613 & 0.92 \\
\hline Ammonia & 189 & $1.082 \pm 0.040$ & $-0.042 \pm 0.056$ & 0.003 & 0.89 \\
\hline Artery & 95 & $0.246 \pm 0.060$ & $0.070 \pm 0.024$ & - & 0.39 \\
\hline Portal vein & 94 & $0.711 \pm 0.123$ & $0.093 \pm 0.063$ & - & 0.52 \\
\hline Urea & 176 & $1.081 \pm 0.011$ & $-0.220 \pm 0.125$ & 0.818 & 0.99 \\
\hline PAH & 186 & $1.426 \pm 0.030$ & $-0.985 \pm 1.499$ & 0.198 & 0.96 \\
\hline
\end{tabular}

\subsection{Measurements of net portal fluxes of metabolites in blood and plasma}

Before comparing net portal fluxes of metabolites between blood and plasma, it was necessary to check the reliability of PAH for both blood and plasma flow measurements. All the PAH in blood was associated with the plasma fraction (table I). Within the wide range of PAH concentrations, from 7 to $21 \mathrm{mg} \cdot \mathrm{L}^{-1}$ blood, PAH concentration in blood was closely and linearly related $(P<0.001)$ to its paired plasma concentration, as observed for all metabolites (table II). Theoretical plasma flows, calculated from measured blood values and PCV, were thus closely and linearly related $(P<0.001)$ to their paired measured plasma flows (figure 1). As expected, the relationship between theoretical and measured plasma flows did not significantly differ from the bisector. PAH is thus a reliable marker for both blood and plasma flow measurements, demonstrating that differences between plasma and blood fluxes of metabolites are only attributable to the relative distribution of metabolites between plasma and cells.
On average, acetate and ammonia net release and urea net uptake through PDV were underestimated by plasma measurements by $7 \%(P<0.001), 9 \%(P<0.001)$ and $17 \%(P<0.002)$, respectively (table III). The ranking of these values is similar to that observed by Huntington [9] and Reynolds and Huntington [18]: 18, 24 and $37 \%$, respectively, but absolute values were lower in our study. This may be because metabolite fluxes were obtained on non-producing ewes in the present study and on lactating cows in the studies of Huntington [9] and Reynolds and Huntington [18]. Due to the absence of $\beta$-hydroxybutyrate within the cell fraction, net release of $\beta$-hydroxybutyrate did not significantly differ between blood and plasma measurements. In ruminants fed forages, glucose uptake by PDV tissues generally exceeds glucose release [10]. This observation is confirmed in the present work. Furthermore, we observed that, on average, PDV net uptake of glucose was overestimated by $39 \%$ in plasma measurements $(P<0.001)$. A similar result was observed by Prior et al. [16] for net uptake of glucose by the hind half of beef steers. Conversely, with a paired $t$ comparison of blood and plasma measurements of net PDV 
Table III. Portal net fluxes ${ }^{\mathrm{a}}$ of metabolites $\left(\mathrm{mmol} \cdot \mathrm{h}^{-1}\right)$ in blood and plasma: paired $t$-test comparison.

\begin{tabular}{lcrrrrr}
\hline & & \multicolumn{2}{c}{ Site } & & \multicolumn{2}{c}{ Paired $t$-test comparison } \\
\cline { 3 - 4 } \cline { 5 - 7 } Item & $n$ & Blood & Plasma & & SED & $P<$ \\
\hline Acetate & 92 & 59.286 & 55.089 & & 0.864 & 0.001 \\
B-Hydroxybutyrate & 89 & 6.057 & 5.808 & & 0.196 & 0.206 \\
Glucose & 83 & -4.762 & -6.638 & & 0.413 & 0.001 \\
Ammonia & 92 & 17.487 & 15.852 & & 0.363 & 0.001 \\
Urea & 79 & -12.517 & -10.377 & & 0.652 & 0.002 \\
\hline
\end{tabular}

${ }^{a}$ Minus sign indicates net uptake; otherwise, net release.

flux of glucose in lactating cows, Huntington [9] found a net release of $8 \mathrm{mmol}$ glucose $\cdot \mathrm{h}^{-1}$ by PDV when measurements were made on plasma, but a net uptake of $41 \mathrm{mmol}$ glucose $\cdot h^{-1}$ when measurements were made on blood. This may be because differences between blood and plasma measurements vary according to the magnitude of the net flux of glucose, as discussed below.

Net flux of acetate, $\beta$-hydroxybutyrate, glucose, ammonia and urea ranged from
+10 to $+120,+0.6$ to $+12,-20$ to +10 , +6 to +30 , and -28 to $-2 \mathrm{mmol} \cdot \mathrm{h}^{-1}$, respectively. As expected, blood values were significantly correlated $(P<0.01)$ with their paired plasma values within this range of flux (figure 2). For acetate, the slope of the relationship did not significantly differ from $1(P>0.05)$. The underestimation of its release by plasma analysis was largely constant, averaging $7 \%$. Reynolds and Huntington [18] discerned two groups of VFA

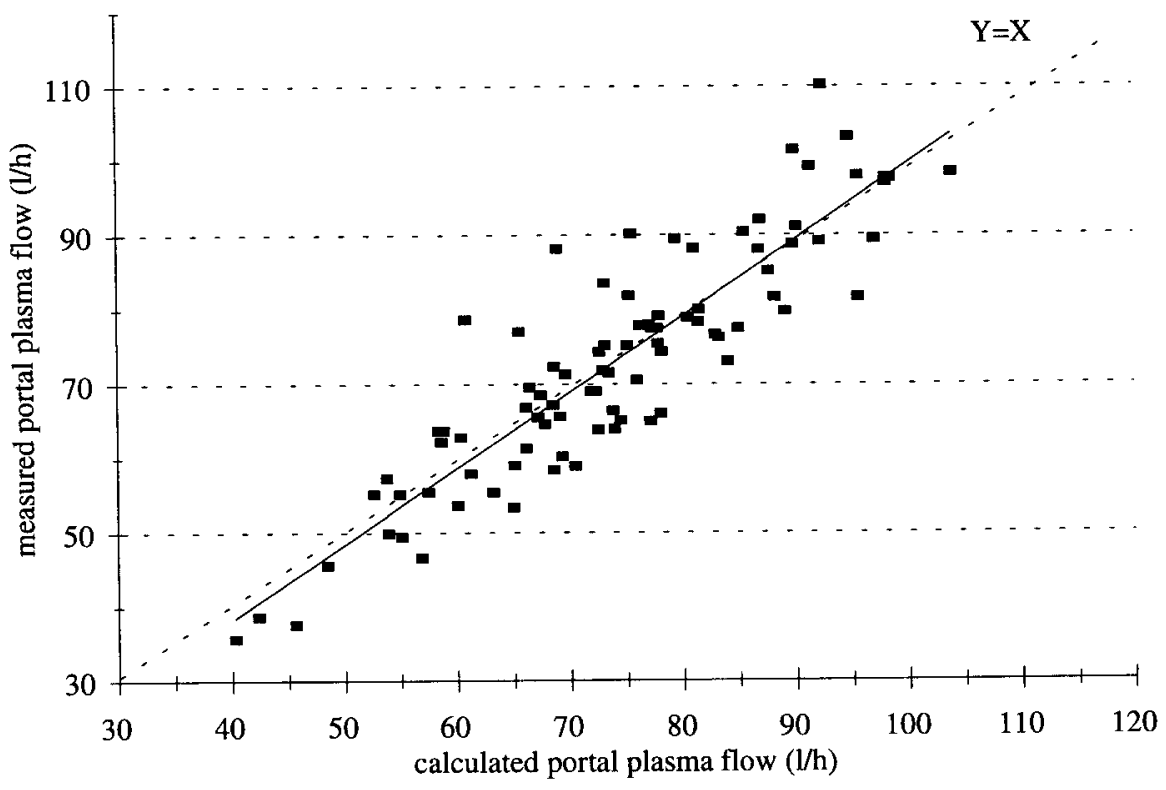

Figure 1. Linear relationship between calculated (from blood values and packed cell volume) $(X)$ and measured $(\mathrm{Y})$ portal plasma flows $(n=89 ; \mathrm{r}=0.89)$ : $\mathrm{Y}=(1.022 \pm 0.055) \mathrm{X}+(-2.637 \pm 7.041)$. 

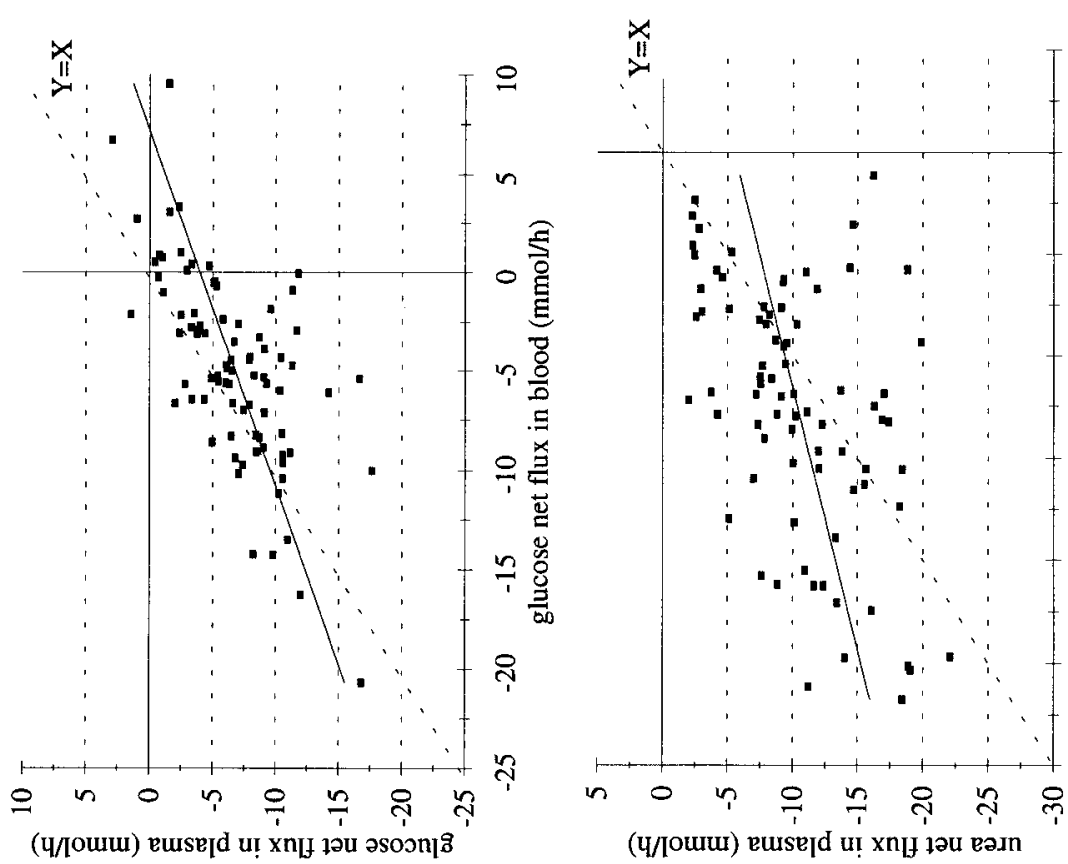

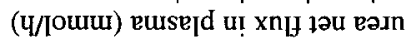
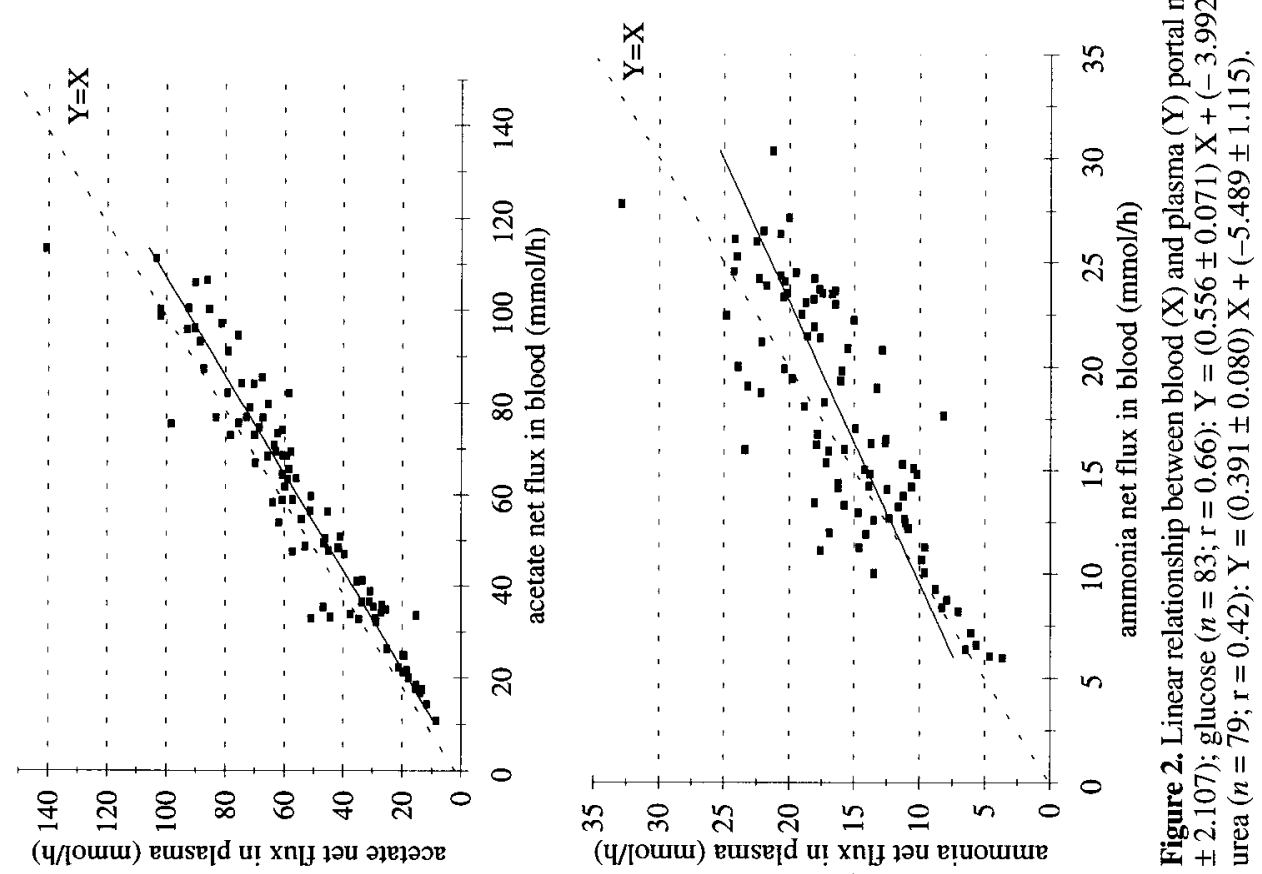
according to the differences between blood and plasma net fluxes through PDV: n-butyrate, i-valerate and n-valerate for which no differences were observed, and acetate, propionate, i-butyrate and 2-methylbutyrate for which plasma measurements underestimated net release by PDV. Their results showed that the underestimation of net release by plasma measurements was similar for the four VFAs in the second group, averaging $15 \%$. Our results suggest that this underestimation is largely constant whatever the magnitude of the flux. Conversely, the slope of the relationship was significantly less than $1(P<0.001)$ for glucose, ammonia and urea, illustrating that for these metabolites differences between blood and plasma measurements vary according to the magnitude of the net flux. Compared with the other metabolites, net PDV flux of glucose can be negative, i.e. net uptake, or positive, i.e. net release, and was either underestimated or overestimated by plasma measurement. According to the linear relationship established in this study, overestimation occurs when net flux is very low, from 10 to $-10 \mathrm{mmol} \cdot \mathrm{h}^{-1}$. This concerns $90 \%$ of the data, explaining the result of the paired $t$ comparison of blood with plasma glucose net fluxes described above. However, underestimation occurs when net uptake is higher than $10 \mathrm{mmol} \cdot \mathrm{h}^{-1}$, reaching $25 \%$ when net uptake of glucose is the highest, i.e. $20 \mathrm{mmol} \cdot \mathrm{h}^{-1}$. The underestimation of net flux by plasma measurements reached $17 \%$ with the highest ammonia net release $\left(30 \mathrm{mmol} \cdot \mathrm{h}^{-1}\right)$ and $41 \%$ with the highest urea net uptake $\left(28 \mathrm{mmol} \cdot \mathrm{h}^{-1}\right)$. These value are in agreement with Huntington [9] who observed in lactating cows fed ad libitum an underestimation of $24 \%$ for ammonia net release and of $37 \%$ for urea net uptake by PDV when measurements were made on plasma.

\section{CONCLUSIONS}

Although they often suffice for comparisons of metabolic profiles, plasma mea- surements appear inadequate when quantitative determinations have to be made. For the determination of metabolic fluxes through PDV, measurements on blood are necessary for ammonia and urea, and preferable for glucose. For acetate, underestimation of net release by plasma measurements is low and largely constant. However, because VFA are the main energy compounds, blood measurements may be preferred for the determination of energy balance. Plasma measurements appear reliable for determination of net release of $\beta$-hydroxybutyrate by PDV.

\section{ACKNOWLEDGEMENTS}

We thank J. Lefaivre for surgery, A. Ollier, A. Combeau and the staff of Les Cèdres for animal care and help with sampling, G. Sauvage and R. Lefaivre for analyses.

\section{REFERENCES}

[1] Annison E.F., Lindsay D.B., Acetate utilization in sheep, Biochem. J. 78 (1961) 777-785.

[2] Arai T., Sagara M., Sako T., Nigi H., D-glucose transport and glycolytic enzyme activities in erythrocytes of dogs, pigs, cat, horses, cattle and sheep, Res. Vet. Sci. 58 (1995) 195-196.

[3] Aubert L., Motais R., Molecular features of organic anion permeability in ox red blood cell, J. Physiol. 246 (1975) 159-179.

[4] Bamouin J., El Idilbi N., Chilliard Y., Chacomac JP., Lefaivre R., Micro-dosage automatisé sans déprotéinisation du 3-hydroxybutyrate plasmatique chez les bovins, Ann. Rech. Vét. 17 (1986) 129-139.

[5] Bergmeyer H.U., Methods of Enzymatic Analysis (2nd English ed.), vol. 1, Verlag Chimie, Weinheim, Germany, 1974.

[6] Bratton C.A., Marshall E.K., A new coupling component for sulfanil-amide determination, J. Biol. Chem. 128 (1939) 537-550.

[7] Chalmers M.I., Grant I., Annand M.G., White F., Free amino-nitrogen used as a monitor for the uptake and movement of amino acids in sheep, J. Agric. Sci. Camb. 89 (1977) 541-550.

[8] Heitmann R.N., Bergman E.N., Transport of amino acids in whole blood and plasma of sheep, Am. J. Physiol. 239 (1980) E242-E247. 
[9] Huntington G.B., Net absorption of glucose and nitrogenous compounds by lactating Holstein cows, J. Dairy Sci. 67 (1984) 1919-1927.

[10] Huntington G.B., Energy metabolism in the digestive tract and liver of cattle: influence of physiological state and nutrition, Reprod. Nutr. Dev. 30 (1990) 35-47.

[11] Inra, Jarrige R. (Ed.), Ruminant Nutrition, Recommended Allowances and Feed Tables, Inra Publications, Paris, France, 1989.

[12] Isserty A., Ortigues I., Rémond D., Mesure des débits splanchniques par dilution de marqueur : comparaison de quatre méthodes de dosage de l'acide para-amino-hippurique, Reprod. Nutr. Dev. 38 (1998) 93-106.

[13] Katz M.L., Bergman E.N., Simultaneous measurements of hepatic and portal blood flow in the sheep and dog, Am. J. Physiol. 216 (1969) 946-952.

[14] Marsh W.H., Fingerhut B., Miller H., Automated and manual direct methods for the determination of blood urea, Clin. Chem. 11 (1965) 624-627.

[15] Ortigues I., Durand D., Lefaivre J., Use of paraamino hippuric acid to measure blood flows through portal-drained-viscera, liver and hindquarters in sheep, J. Agric. Sci., Camb. 122 (1994) 299--308.

[16] Prior R.L., Huntington G.B., Reynolds P.J., Role of insulin and glucose on metabolite uptake by the hind half of beef steers, J. Anim. Sci. 58 (1984) 1446-1453.

[17] Rémond D., Chaise J.P., Delval E., Poncet C., Net flux of metabolites across the ruminal wall of sheep fed twice a day with orchardgrass hay, J. Anim. Sci. 71 (1993) 2529-2538.

[18] Reynolds P.J., Huntington G.B., Net portal absorption of volatile fatty acids and $\mathrm{L}(+)$-lactate by lactating Holstein cows, J. Dairy Sci. 71 (1988) 124-133.

[19] Sands J.M., Timmer R.T., Gunn R.B., Urea transporters in kidney and erythrocytes, Am. J. Physiol. 273 (Renal Physiol. 42) (1997) F321-F339.

[20] SAS, SAS user's guide, SAS Inst., Inc., Cary, N.C., 1988.

[21] Weatherburn M.W., Phenol-hypochlorite reaction for determination of ammonia, Anal. Chem. 39 (1967) 971-973. 